\title{
Geographical Indication Helvas in Turkey
}

\author{
Abdullah Badem
}

Department of Hotel Restaurant and Catering, Karamanoglu Mehmetbey University, Karaman, Turkey

Received: 02 Nov 2020; Received in revised form: 10 Dec 2020; Accepted: 21 Dec 2020; Available online: 28 Dec 2020 (C)2020 The Author(s). Published by Infogain Publication. This is an open access article under the CC BY license (https://creativecommons.org/licenses/by/4.0/).

\begin{abstract}
Sociologically, all values acquired over time are expressed as culture. Food and drink, which is one of the natural activities of human beings, that is, all kinds of nutritional activities, preparation of meals, even table setting are included in the culture. Seljuk / Ottoman cuisine has a very rich and deeprooted history, and its continuation Turkish cuisine is also very rich. This wealth has come about by living together with many nations and having cultural interaction. Food groups and ingredients in Turkish cuisine are quite high and desserts have an important place among them. When it comes to Turkish cuisine dessert, baklava and Turkish delight come first. In addition to these, there are also helvas produced with a wide type of ingredients and different methods. The name of helva is derived from the Arabic word "hulv" and its plural "hulviyyat" is used to mean "sweets". In its simplest form, halva is obtained by adding sugar syrup to flour roasted in oil. Of course, the way of making helva, which has many types, is also unique to each helva. Provided a specially produced meal is identified with the region or country in which it is made in terms of its characteristics, recording it is called a geographical indication to be recorded under certain conditions. In Turkey there are currently 10 geographical indication helva. There are also dozens of meals and desserts whose geographical indication process continues. Gastronomy tourism is briefly tasting a meal and seeing the preparation process of the meal on making process. Expansion of the tour destination by including meals in cultural tours continues with the increasing trend in recent years. With this article, it is aimed to introduce Turkish cuisine, in terms of sustainability, desserts and helvas among desserts in the international arena and to increase their awareness. In addition, the suggestion of including Turkish sweets and helvas at designing destination was emphasized in the touristic or gastronomic tours to be organized in Turkey.
\end{abstract}

Keywords-Gastronomy tourism, Geographical indication, Helva, Ottoman cuisine, Seljuk cuisine, Turkish cuisine, Turkish deserts.

\section{INTRODUCTION}

Turkish cuisine, together with Chinese and French cuisines, is considered among the richest and most popular cuisines in the world [1]. Every society or nation that they come into contact with has more or less added something to Turkish cuisine culture [2]. Sometimes the tastes that do not fit the taste of the Turkish society have turned into dishes suitable for their own taste. There is a rich variety of dishes in Turkish cuisine that has been going on since Seljuk and Ottoman cuisine. There are various types of dishes such as soups, appetizers, meat dishes, offal dishes, vegetable and fruit dishes, rice dishes, pastries, drinks, and besides these types, desserts also have a very rich variety. Desserts in Turkish cuisine, which is a continuation of Seljuk and Ottoman Empire cuisine, can be evaluated in four groups. These are: i) sweet dough desserts, ii) helvas, ISSN: 2456-7620

https://dx.doi.org/10.22161/ijels.56.63 iii) milky-slightly desserts and confectionery, and iv) fruit desserts [3,4]. Yerasimos [3], who compiled the 500-yearold dishes of Ottoman cuisine with a rich culinary culture, says that the most recipes on the food list are in desserts. Many types of helva are mentioned among these desserts. In Evliya Çelebi's Travel Book, 58 types of sweet dough dessert and helva are mentioned among 303 desserts [5]. Oturakçı Orbay [6] mentions 940 dessert names in modern Turkish. In Turkey, there are still dozens of helva made at a local level or at industrial scale in many regions. There are only 10 helvas with geographical indications and 15 pieces of helva whose geographical indication process continues. The name halva is derived from the Arabic word "hulv", and its plural means "hulviyyat", meaning "sweets". Helva, which means "sweet", is expressed as "dessert made with all kinds of flour/starch, fat, honey or 
Nov-Dec 2020 / Available online: https://ijels.com/

sugar" $[7,8,9]$. The simple, prototype helva is "flour helva", and its production is given as "adding sugar syrup to flour roasted in oil" [4]. The names given to helva in different languages are "halawa, halva, halvah, halava, helva and halwa". Helva is made in places where Turks, Arabs and Jews live and is known in Turkey, Middle East, Eastern Mediterranean, Central Asian and African countries [10]. Turks met with helva after the adoption of Islam [9].

Topkap1 Palace in Istanbul was built by Fatih Sultan Mehmet between 1475-1478. There is also "Helvahane", which is a kitchen section where dessert is made, in the kitchen with an area of $5.250 \mathrm{~m} 2$ in the palace. Arabs use the word "helva" to mean "desserts". It is stated that the reason why the part of the palace where dessert is made is called "Helvahane" is due to this. It is known that various desserts are made in Helvahane and even medicines and strengthening mixtures (macun=paste), sherbets, compotes, jams and syrups are prepared [3,8,9]. 812 people were working under the supervision of "Helvacibaşı", Helvahane manager, in the 16th century [3]. Topkapı Helvahane is known as the first kitchen in the world cuisine history to be used separately from the place where meals are cooked [11]. The kitchen in the palace was the center of attention for many foreigners even at that time, and it was stated what efforts were made to see and visit the palace [12]. The existence of Helvahane, which is a separate section in the palace, supports the special place of helva in Turkish culture. In addition, it is known that helva was eaten and chatted in meetings with state officials and other meetings held on long winter evenings. Named these conversations "helva conversations" stands out as another gastronomic activity $[4,7,8,13]$. The fact that Turkey's many different varieties of halva and components made in many parts of the Seljuk / Ottoman cuisine is the proof that sustainable. One of the important desserts in Turkish cuisine, helva is still served on special days such as births, weddings, death ceremonies and religious holidays, and continues its existence as a ritual, and a sacred and cultural activity [7,9,10]. Turkish life begins with dessert and ends with dessert. In other words, it is seen that the first symbolic food of the transitional periods such as birth, engagement, marriage, circumcision and even death is often sweet. In addition to these, the sweet's expressions such as "May God give you a taste of the mouth= God bless you, let's eat sweet, talk sweet, I cut to your voice with honey= I get in the middle of the conversation, but I have to." [14] and someone calling the person she loved "honey, sweetie" [2], shows that it is also effective in shaping the life of Turks in terms of sociologic. The fact that "Ramadan Feast", one of the religious days, was called "Feast of Sugar" in the Ottoman period in the 18th century proves that dessert is in every aspect of Turks life [7]. Gastronomy tourism can be defined as visiting food/meal producers, food/meal festivals, restaurants and special areas in order to taste a special meal or to see the production of a meal [15]. It should be used to introduce that culture for reasons such as the use of locally made desserts on special days and celebrations and being a symbol of festivals. In this context, in terms of sustainability, it is important that helva be evaluated within the scope of gastronomy tourism and included in the destination of tours by tour operators $[8,9]$. In addition, geographical indication is required to protect these locally produced products. With this study, With this study, it is aimed to emphasize introduction of helva belong to rich culinary culture of Turkey, announcement of Turkey's geographical indication helvas in the international arena, to be considered for use in both local and international gastronomy tours, and the necessity of gastronomy tours with "geographically marked products" theme.

\section{MATERIAL AND METHOD}

In this study, it was selected for introduction of Turkey's geographical indication helvas and for evaluation in terms of gastronomic tourism. In Turkey, Turkish Patent Institute, authorized for geographical indication, based on the geographical indication helvas on the official website [16] in order to create the list were used descriptive research type and detailed description of helva such as the place of production, production method and properties are defined. In this study, which is a qualitative study, the literature was also searched and the books written on the subject were used.

\section{GEOGRAPHICAL INDICATION HELVAS}

"Geographical indication is a quality mark that indicates and guarantees the connection between the source, characteristics and features of the product and the geographical area for consumers. With the registration of geographical indication, it is ensured that products that have gained a certain reputation depending on their quality, tradition, ingredients obtained from the region and local qualities are protected. A geographical indication is a marker that indicates the product identified with the region, area, region or country where the origin is located in terms of a distinct quality, reputation or other features " [17]. The role of geographical indication in the protection of culture and its effect on regional development is known. Especially the strong connection between food/mealculture-place relationship has increased the importance of the geographical indication [18]. With the geographical indication, both the consumer and the producer are 
Nov-Dec 2020 / Available online: https://ijels.com/

protected, as well as rural development is provided, and the countries can protect their cultural values and transfer them to other generations [19]. There are many helvas locally produced in Turkey. As of the writing date of the article, the place of production, production method and properties of 10 piece of geographical indication helvas are given in this article. The helvas that have been applied to Turkish Patent Institute and whose geographical indication process continues are as Aksaray Köpük Helva, Antep Peynirli İrmik (with cheese, semolina) Helva, Bursa Süt (Milky) Helva, Deva-i Misk Helva, Düzce Fındıklı Tahin (Hazelnut Tahini) Helva, Erzurum Peynir (Cheese) Helva, Eskişehir Nuga Helva, Gerze Dügün (Wedding) Helva, Kahta Bademli İrmik (with almond, semolina) Helva, Konya Haside Tatlısı (Dessert) - Kara (black) Helva, Konya İrmik (Semolina) Helva, Konya Kenevir (hemp) Helva, Kütahya Bitli Helva, Mudurnu Basma Helva ve Paşa (pasha) Helva. The high number of helva mentioned increases its importance in terms of gastronomy tourism and reveals the necessity to increase its awareness in the field of international tourism. Ten pieces of geographical indication helva are detailed below. Detailed information about helvas whose geographical indication process continues and geographical indication registered is given in Table 7 at the end of the article.

\subsection{Bilecik Pazaryeri Helva}

Bilecik Pazaryeri Helva is a type of helva produced in Pazaryeri district in Bilecik province. Helva is produced in specially designed copper boilers. Only tahini, beet sugar and water are used in the production of helva. Filling materials such as semolina and flour cannot be used in helva production. Tahini used in production should be produced only from sesame, and no other additives or preservatives should be added to the helva. The master who decides what to do and when, during the mixing and cooking of the mentioned ingredients, is the most important factor in the production. While other types of helva are boiled at $140-150^{\circ} \mathrm{C}$, the boiling temperature of Bilecik Pazaryeri Helva is $117-118^{\circ} \mathrm{C}$. The ingredient ratios required for the production of Bilecik Pazaryeri Helva: $45-48 \%$ tahini, $41-45 \%$ sugar and $8-12 \%$ water. The production of helva starts by melting the required amount of sugar in water and mixing and boiling at 117 $118^{\circ} \mathrm{C}$, and the sugar in the mixture is given a viscous structure during boiling. Then, continuing to mix, tahini is added to mix. When the product reaches its unique structure, it is taken to the resting pans and waited for the product to cool and rest. The manufacturing process takes about 14-16 hours. The photo of helva is given in Figure 1 and some chemical properties of helva are given in Table 1.

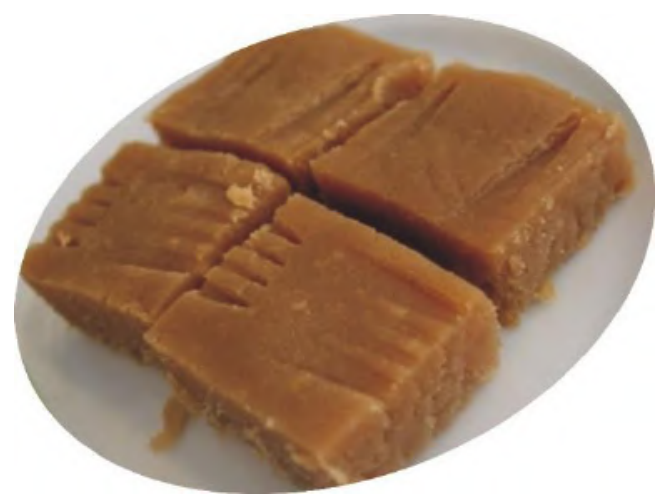

Fig. 1: Bilecik Pazaryeri Helva.

\subsection{Cide Ceviz (Walnut) Helva}

Cide Ceviz Helva is a helva prepared in 3.5-4 hours by adding plenty of walnut to a mixture of beet sugar, egg whites, citric acid and water. Helva, which has been produced for many years in Cide district in Kastamonu province, has also been identified with special days (before wedding ceremonies, buying helva for eating after religious days such as Feast of Ramadan and Feast of Sacrifice prayer). The most important thing that gives helva its distinctive qualities is to provide sugar viscous structure at $143 \pm 2^{\circ} \mathrm{C}$. The production temperature is important and a viscous and unique product is formed with viscous structure. Below $140^{\circ} \mathrm{C}$, the gel cannot find enough viscous structure and occur loose form, while the gel made from mix taken above $145^{\circ} \mathrm{C}$ becomes a lighter viscous.

Table 1: Some chemical properties of Bilecik Pazaryeri Helva.

\begin{tabular}{lr}
\hline Properties & Quantity \\
\hline Energy $(\mathrm{kcal} / 100 \mathrm{~g})$ & 620 \\
\hline Protein $(\mathrm{g} / 100 \mathrm{~g})$ & 17.8 \\
\hline Lipid $(\mathrm{g} / 100 \mathrm{~g})$ & 39.5 \\
\hline $\begin{array}{l}\text { Carbohydrate } \\
\text { (g/100g) }\end{array}$ & 48.4 \\
\hline $\begin{array}{l}\text { Dietary Fiber } \\
\text { (g/100g) }\end{array}$ & 0.26 \\
\hline $\begin{array}{l}\text { Cholesterol } \\
(\mathrm{mg} / 100 \mathrm{~g})\end{array}$ & 0 \\
\hline Sodium $(\mathrm{mg} / 100 \mathrm{~g})$ & 115 \\
\hline Potassium $(\mathrm{mg} / 100 \mathrm{~g})$ & 10 \\
\hline Calcium $(\mathrm{mg} / 100 \mathrm{~g})$ & 15 \\
\hline $\begin{array}{l}\text { Vitamin A } \\
(\mathrm{mg} / 100 \mathrm{~g})\end{array}$ & 0.1 \\
\hline Vitamin C $(\mathrm{mg} / 100 \mathrm{~g})$ & 0 \\
\hline
\end{tabular}


Nov-Dec 2020 / Available online: https://ijels.com/

\begin{tabular}{ll}
\hline Iron $(\mathrm{mg} / 100 \mathrm{~g})$ & 0.28 \\
\hline Acidity $(\mathrm{g} / 100 \mathrm{~g})$ & 1.98 \\
\hline Ash $(\mathrm{g} / 100 \mathrm{~g})$ & 1.92 \\
\hline Moisture $(\mathrm{g} / 100 \mathrm{~g})$ & 3.84 \\
\hline
\end{tabular}

Required ingredients for the production of $10 \mathrm{~kg}$ of Cide Ceviz Helva: $8 \pm 1 \mathrm{~kg}$ walnuts, $10 \pm 1 \mathrm{~kg}$ sugars, $1.150 \pm 50 \mathrm{~g}$ egg whites, $13.50 \pm 1 \mathrm{~g}$ lemon salts (citric acids). For helva production, sugar and water are mixed in boiler, boiled for 4 hours, lemon salt is added. Lemon salt increases the shelf life of helva. The desired density can be obtained by mixing the mixture, otherwise the sugar may become caramelized at high temperature, which causes unwanted and negative effects on the final product. The mixture is taken at $143 \pm 2{ }^{\circ} \mathrm{C}$, after cooling to $40 \pm 5^{\circ} \mathrm{C}$, whipped egg whites are added. Egg whites give the helva a shiny appereance. Although the final product has the hardness to be cut with a knife, it provides the texture that will cause disintegration when cut. The mixture is put on the fire again, it is mixed and cooked for 2 hours until it reaches the gumy consistency. When the final viscous structure is obtained, walnuts are added. After, helva is cooled to 18$22^{\circ} \mathrm{C}$. If the helva gets colder, it will be difficult to cut it. It is recommended that helva be consumed one day after being packaged. The final form of helva is given in Figure 2 , and its physical and chemical properties are given in Table 2.

\subsection{Kabataş Helva}

Homemade pekmez (molasses) and walnut are used in the production of Kabataş Helva, a helva specific to Kabataş district in Ordu province. Required ingredients for the production of $10 \mathrm{~kg}$ Kabataş Helva: $3 \mathrm{~kg}$ walnuts, $4 \mathrm{~kg}$ homemade pears or apple pekmez (molasseses), $2 \mathrm{~kg}$ beet sugars, $1 \mathrm{~kg}$ wheat flour, $10 \mathrm{egg}$ whites, $5 \mathrm{~g}$ lemon salt $\mathrm{s}$ (citric acids).

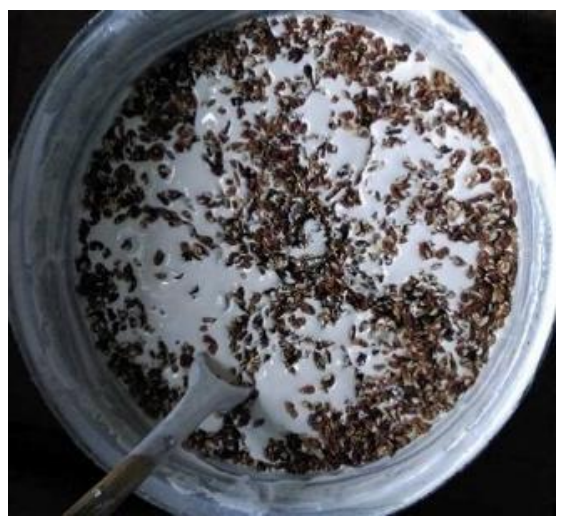

Fig. 2: Cide Ceviz Helva.
Table 2: Some physical and chemical properties of Cide Ceviz Helva.

\begin{tabular}{lr}
\hline Properties & Quantity \\
\hline Walnut (min, \%) & 40 \\
\hline $\mathrm{pH}$ & $6,00 \pm 0,40$ \\
\hline $\begin{array}{l}\text { Total sugar } \\
\text { (sucrose type, max, \%) }\end{array}$ \\
\hline Protein (\%) \\
\hline Lipid (\%) & $9,15 \pm 0,25$ \\
\hline Mousture (max, \%) & $2,10 \pm 0,20$ \\
\hline Ash (max, \%) & 8,50 \\
\hline Acidity & $0,65 \pm 0,05$ \\
\hline (oleic acid type, max, \%) & 0,65 \\
\hline
\end{tabular}

The tolerance for the ingredients used should be 5-6\% at most. Pekmez (molasses) is boiled in a pan over low heat by mixing for 2 hours until it reaches the gumy consistency. At this stage, the amount of pekmez (molasses) that is $4 \mathrm{~kg}$ decreases to $2 \mathrm{~kg}$ with the evaporation of water. In another heated pan, half a liter of water and sugar are mixed for 4 hours and become syrup, lemon salt is added during boiling and the syrup has turned yellow in the last stage. The syrup and pekmez (molasses) are mixed and cooked for 2 hours and the mixture becomes the gumy consistency. The mixture is cooled slowly, whipped egg whites are added while it is warm, the mix is put on the fire again, it is mixed until it has a gumy consistency for 2 hours. Then, roasted wheat flour and walnuts are added to the mixture. The mixture, which has now become helva, is taken to vessels. Helva is cut into slices at $20-30^{\circ} \mathrm{C}$ as in Figure 3 and rested for 24 hours. The photo of helva is given in Figure 3 and chemical properties of helva are given in Table 3.

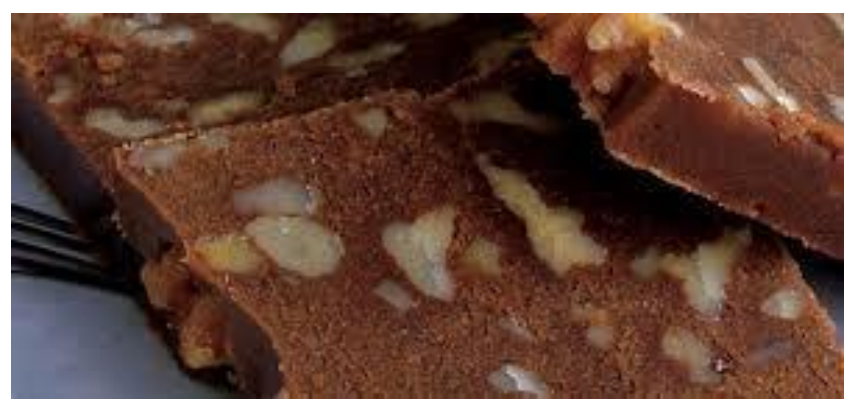

Fig. 3: Kabataş Helva. 
Table 3: Some chemical properties of Kabataş Helva.

\begin{tabular}{lr}
\hline Properties & Quantity (\%) \\
\hline Lipid & $1-4$ \\
\hline Protein & $4-7$ \\
\hline Total sugar & 60 \\
(sucrose type, max) & 3,5 \\
\hline Mousture (max) & 1 \\
\hline Ash (max) & 1,3 \\
\hline Acidity & \\
(oleic acid type, max) & \\
\hline
\end{tabular}

\subsection{Kastamonu Çekme (Pulled) Helva}

Produced in Kastamonu province, Kastamonu Çekme Helva is prepared with the addition of beet sugar, wheat flour, butter and/or vegetable margarine, water, citric acid, flavoring and aromatic food in accordance with the Çekme Helva Standard [20] (TSI; TS 13028). While helva is traditionally produced plain, different types of helva are also produced with the addition of pistachios, walnuts, almonds, hazelnuts, cocoa, chocolate, coconut and sesame. Only vanilla/vanillin and lemon salt (citric acid) can be used as food additives in its production. Since the 1800s, helva has also been used to celebrate special days such as birth and marriage. Helva, known to be sent to the Ottoman Palace, has become a part of our culture as traditional foods like our other helva.

Ingredients used in the production of Kastamonu Çekme Helva: butter/vegetable margarine $16 \pm 2 \%$, wheat flour $48 \pm 2 \%$, beet sugar $34 \pm 4 \%$, water $2 \pm 2 \%$ and citric acid $0.01 \%$. In the production of helva, firstly, miyane is prepared. Miyane is prepared in cooking vessels at $160 \pm 15^{\circ} \mathrm{C}$ by adding flour into the melted oil for $3-4$ hours. Roasted miyane is one of the factor that give the taste and smell authenticity of helva. The high rate of miyane in Kastamonu Çekme Helva ensures that the sugar content is low in the total content, the sugar taste is felt less while the product is consumed, and the final product is lighter. In another boiler, sugar and water are melted and boiled at $130 \pm 10^{\circ} \mathrm{C}$ for 20 minutes. Before the boiling process is completed, citric acid is added and mixed. The mixture is poured into a thin layer on the cooling workbench and spread. During the cooling phase of the sugar, the temperature of the sugar is reduced to $85 \pm 10^{\circ} \mathrm{C}$ by folding it several times to prevent crystallization and to cool the lower parts. The bleaching process is started by attaching to the arms of the sugar bleaching machine and takes about 5 minutes until the color of the sugar mass turns white. Cooked miyane and bleached sugar are taken to the workbench and formed into a large ring. The sugar ring, which is covered with miyane, is extended by turning and pulling from hand to hand. This is why it is called "çekme = pulled" helva. The growing ring is made into a shape of eight and folded over one another. This process continues for 20-25 minutes until the sugar mass and the miyane are homogeneously dispersed within each other. At the last stage, there should not be any rough sugar and miyane lumps in the mass, the helva after the pulling process should have become thin and stringy. Then it is laid on the workbench to cool and left for about 20 minutes. Helva, whose temperature is reduced to $25 \pm 5^{\circ} \mathrm{C}$, is thrown into the grinding machine. The critical point in this process is that the temperatures of the miyane and the bleached sugar mass are close to each other in order to ensure a homogeneous mixture. Although there is a similar process flow in many types of Çekme Helva up to this stage, the process step that distinguishes Kastamonu Çekme Helva from its counterparts is to continue the processing of the helva mass, crushing the sugar fibers in the helva with knives by pouring it into the grinding machine and giving it a mealy, pourable form. After this process, the helva mass is placed in trays and given to the pressing machine. Compressed helva in the pressing machine gains a distinctive smooth and tight form. The final product is filled in boxes and sealed, packaging is completed in the shrink machine and stored in the cool area at $20 \pm 2^{\circ} \mathrm{C}$. Helva has a smooth, soft texture that dissolves in the mouth when bitten and during eating, does not stick, does not resist chewing, melts and is easily swallowed, and a color that increases its appeal. The image of helva is given in Figure 4, and its physical and chemical properties are given in Table 4.

\subsection{Ordu Perşembe Ceviz (Walnut) Helva}

Ordu Perşembe Ceviz Helva, produced in Perşembe district in Ordu province, is a type of dessert unique to this region. The ingredients used in making Ordu Perşembe Ceviz Helva: beet sugar, water, gypsophila extract, walnut and lemon salt. Although pekmez (molasses) was used in the production of helva before, today beet sugar is used. For the production of helva, it is melted by mixing with $200 \mathrm{~kg}$ sugars and 100 liters of water, and boiled for 2 hours at $140^{\circ} \mathrm{C} .20$ grams of lemon powder (citric acid) is added to the syrup mixture. The gypsophila extract prepared previously is added. The extract is obtained by boiling the root of the gypsophila plant (Saponaia officinalis). The main component of the gypsophila plant is saponin, and it is used as a bleaching additive in the production of some helva and Turkish delight. The crude saponin amount of the gypsophila plant grown in Anatolia varies between $10-25 \%$. In the production of helva, $0.5 \mathrm{~kg}$ 
Nov-Dec 2020 / Available online: https://ijels.com/

of gypsophila extract is usually sufficient for $100 \mathrm{~kg}$ helva. Mixing is continued without foaming for a few more minutes after the addition of the gypsophila extract. Then, 20-25\% walnuts are mixed into the mixture and left to cool. When the helva temperature drops to $20-30^{\circ} \mathrm{C}$, cutting process is done. If the helva cools down completely, it will be very difficult to cut. After slicing, it is recommended to rest for 1 day in order to obtain a suitable consistency. The image of helva is given in Figure 5 and its chemical properties are given in Table 5.

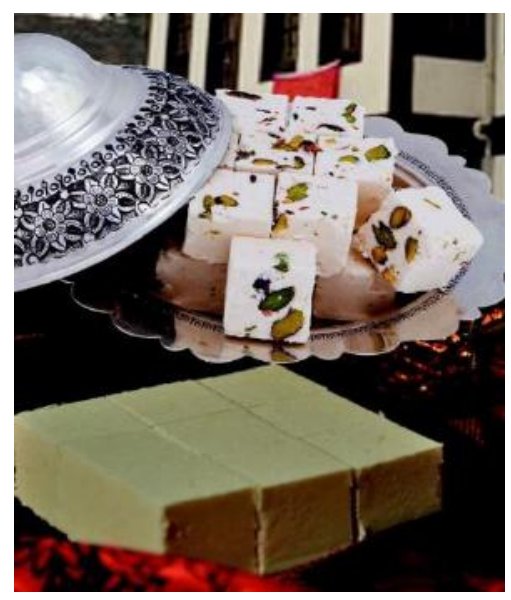

Fig. 4: Kastamonu Çekme Helva.

Table 4: Some physical and chemical properties of Kastamonu Çekme Helva.

\begin{tabular}{lr}
\hline Properties & Quantity \\
\hline Moisture, $\%$ & $6 \pm 1.5$ \\
\hline Total sugar & $34 \pm 4$ \\
sucrose type, \% & \\
\hline
\end{tabular}

\begin{tabular}{lr}
\hline Lipid, \% & $16 \pm 2$ \\
\hline ash, \% & $0.50 \pm 0.1$ \\
\hline $\begin{array}{l}\text { Peroxide, } \\
\text { in extracted oil, meq/kg }\end{array}$ & $10 \pm 1.5$ \\
\hline
\end{tabular}

\begin{tabular}{lr}
\hline Colour L & $90.16 \pm 3.5$ \\
\hline $\mathrm{A}$ & $0.90 \pm 0.09$ \\
\hline $\mathrm{B}$ & $16.18 \pm 1.4$ \\
\hline Hardness, g & $546.55 \pm 117.21$ \\
\hline Springiness, mm & $0.159 \pm 0.061$ \\
\hline Cohesiveness & $0.046 \pm 0.007$ \\
\hline Chewiness, gmm & $4.636 \pm 1.253$
\end{tabular}

\subsection{Eskişehir Met Helva}

It is a round, horizontally shaped helva with a diameter of $2 \mathrm{~cm}$ and a length of $7.5 \mathrm{~cm}$, produced in Eskişehir province, made into fiber using wheat flour, oil, beet sugar, citric acid and water. It is rumored that Eskişehir Met Helva got its name from a street game played with met (rod) and anklebone. At the same time, Met Helva is a tradition that the person who is taken a beat as a result of this game makes helva as punishment.

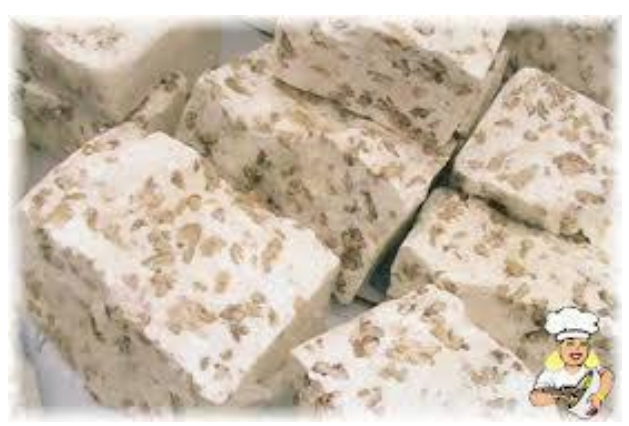

Fig. 5: Ordu Persembe Ceviz Helva.

Table 5: Some chemical properties of Ordu Persembe Ceviz Helva.

\begin{tabular}{lr}
\hline Properties & Quantity (\%) \\
\hline Lipid & $1-5$ \\
\hline Protein & $2-6$ \\
\hline Total sugar & 70 \\
(sucrose type, max) & \\
\hline Moisture (max) & 3,5 \\
\hline Ash (max) & 1 \\
\hline Acidity & 0,5 \\
(oleic acid type, max) & \\
\hline
\end{tabular}

Ingredients used in the production of Eskişehir Met Helva; $50 \mathrm{~kg}$ of wheat flour, 18 liters of sunflower oil, 12 $\mathrm{kg}$ of beet sugar, 4-5 liters of water, $12 \mathrm{ml}$ of citric acid, (200 $\mathrm{g}$ cocoa for cocoa production). For the production of helva, flour and oil are added to the boiler on a low heat between $75-85^{\circ} \mathrm{C}$. If helva with cocoa is to be made, cocoa is also added. Roasting process continues for 4-4.5 hours with continuous mixing. Then it is rested for 1 day at room temperature. Sugar, water and citric acid are added to the boiler. Boiling is done until the mixture temperature reaches $140^{\circ} \mathrm{C}$. After boiling, it is laid on the marble workbench and left to cool. After the sherbet cools down, bleaching is done by hanging it on the bleaching hanger. The sugar syrup is first turned into a cylinder and then rolled into a circle. The dough prepared in the first stage is spread in a thickness of $4-5 \mathrm{~cm}$ in the tray. Sugar in a circle is placed on the dough and covered with dough. The circle is expanded to the size of the tray by pulling the sugar coated dough with 5-7 people around the tray. The 
Nov-Dec 2020 / Available online: https://ijels.com/

dough sugar mixture is folded and kneaded and pulled until it becomes homogeneous. The final mixture is broken with a diameter of $4-5 \mathrm{~cm}$ and a length of $30-35 \mathrm{~cm}$. These pieces are processed by hand until they reach a length of $120-125 \mathrm{~cm}$ with a diameter of $2 \mathrm{~cm}$ and are cut into $2 \mathrm{~cm}$ diameter and $7.5 \mathrm{~cm}$ length by hand or machine and made ready for packaging. It is filled in the desired size boxes. Helva photo is given in Figure 6.

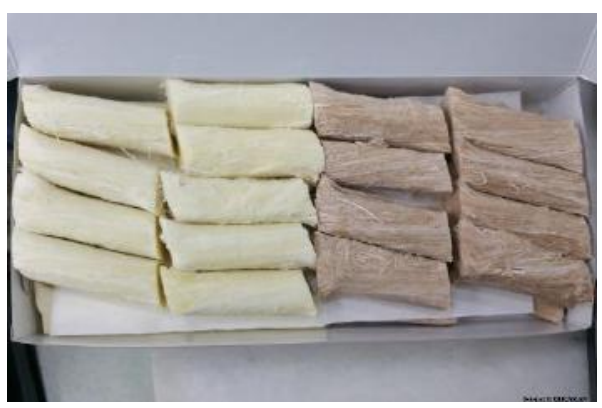

Fig. 6: Eskişehir Met Helva [21].

\subsection{Nazilli Kar (Snow) Helva}

Nazilli Kar Helva is a refreshing drink consumed especially in the summer season in Aydın province, Nazilli district and six districts surrounding Nazilli (Kuyucak, Karacasu, Bozdoğan, Yenipazar, Sultanhisar, Buharkent). Although there are no known helva ingredients such as sugar, flour and oil in its composition, there is the phrase "helva" in its name. Only natural snow and cherry syrup is used in its production. Natural snow and cherry syrup obtained from the mountains and plateaus around Nazilli is used in making helva. Snow kept in the snow cavities until the end of summer does not pose any health problems. One-to-one amount of sugar is added to sour cherries collected in summer. A layer of sour cherry and a layer of sugar are placed in a bowl and the bowl is kept for 1 day by closed. The mixture is boiled over high heat until it becomes jam-like, and it is filtered to separate the seeds. The fruit rate of cherry jam used in making cherry syrup should be in the range of $35-50 \%$. After the jam is filtered, it is diluted with drinking water up to $55 \pm 10^{\circ}$ Brix. It is kept in the refrigerator in jars. Helva is prepared in a glass cup and served with a dessert spoon. The reason why the product is prepared in a glass cup is that the glass keeps the cold for a longer time and allows the appetizing color formed by mixing the snow particles with cherry syrup. Helva should be consumed as soon as it is prepared, otherwise it loses its taste and properties if it is kept or stored in the refrigerator. The snow is filled into the glass approximately $2 / 3$ of the glass. The filled snow should not be clumped or formed into an ice mold. The glass is filled completely and served by adding previously prepared cold cherry syrup on it. Nazilli Kar Helva should be consumed as soon as it is prepared. It loses its taste and properties if it is kept waiting or stored in the refrigerator. Ready-toserve helva is given in Figure 7.

\subsection{Tekirdağ Peynir (Cheese) Helva}

Identified with the province of Tekirdağ, Tekirdağ Peynir Helva has its own bright yellow color, homogeneous structure, fibrous appearance and is produced using saltfree cheese (curd), beet sugar, wheat flour, egg yolk or coloring (E160a-carotene). No preservative additives are used in the production of helva.

Ingredients used in the production of Tekirdağ Peynir Helva; $29-34 \%$ beet sugar, 52-56\% unsalted cheese (curd), 9-12\% durum wheat flour, 4-6\% sunflower oil, egg yolk or colorant (E160a-carotene). Milk to be used in production is subjected to heat treatment up to $36-40^{\circ} \mathrm{C}$. Milk taken into the cheese vessel is fermented with rennet. 13-30 minutes is waited for the fermented milk to coagulate. The curd that reaches the cut ripening is cut, curd and whey are separated from each other. Curd is pressed for 1-1.5 hours and $79-82 \%$ of whey is filtered. The cheese that reaches the desired ripening is chopped. The cheese is taken into the cooking boiler and 4-6\% of the cheese amount is added to the sunflower oil to prevent it from burning during cooking. When the cheese heated at high heat reaches 83$85^{\circ} \mathrm{C}$, coloring or egg yolk is added. When the cheese starts to melt and reaches its consistency, 9-12\% flour is added. It is continued to be heated by mixing over high heat until the flour smell in the mixture disappears. If the cooking process is done more than necessary, fibrous structure will not form, and if less, the cheese does not identify with flour, water release and a opaque appearance occurs in the final product. Finally, sugar is added and mixed for 5-10 minutes to melt and mix the sugar. Helva is cooled up to $25^{\circ} \mathrm{C}$ and filled in the packages. Helva is stored at $0-4{ }^{\circ} \mathrm{C}$. The photo of helva is given in Figure 8 .

\subsection{Gerede Şakşak Helva}

Gerede Şakşak Helva is a helva produced in Gerede district of Bolu province, with the same formula, quality and taste since the 1850s, using beet sugar, walnut and gypsophila (Radix saponariae albae sive L.) extract. Gerede Şakşak Helva is the symbol of the Traditional Gerede Fair, which is established in the third week of september and the first week of october every year, and is one of the most preferred products in the fair. Helva is slightly hard, meltable in the mouth and in the consistency of chewing gum.

The amount of ingredients used in the production of Gerede Şakşak Helva: beet sugar 66\%, glucose 12\%, walnut $20 \%$, gypsophila $1 \%$, lemon salt (citric acid) $1 \%$. For the production of helva, the boiling process is started with $50 \mathrm{~kg}$ sugar and $20 \mathrm{~kg}$ water taken in tinned copper boiler. Boiling is done up to $140^{\circ} \mathrm{C}$ in summer and $135^{\circ} \mathrm{C}$ 
Nov-Dec 2020 / Available online: https://ijels.com/

in winter. Lemon salt is added to avoid sugar during boiling. This process is done for easy melting of the helva in the mouth. Gypsophila extract is used to bleach helva. $150 \mathrm{ml}$ gypsophila extract and $150 \mathrm{ml}$ water are mixed and whisked in the whisk until it turns white and becomes foam. $6 \mathrm{~kg}$ glucose is added in order for the mix to have the gumy consistency. This bleaching process takes 15 minutes. The prepared gypsophila extract is added to the mixture and mixed for 25 minutes. Walnut is added to the mixture close to cooling, mixed, poured into molds, left to cool for 24 hours. After it cools down, it is broken into pieces and made ready to eat in a bite-sized piece and packaged. The photo of helva is given in Figure 9.

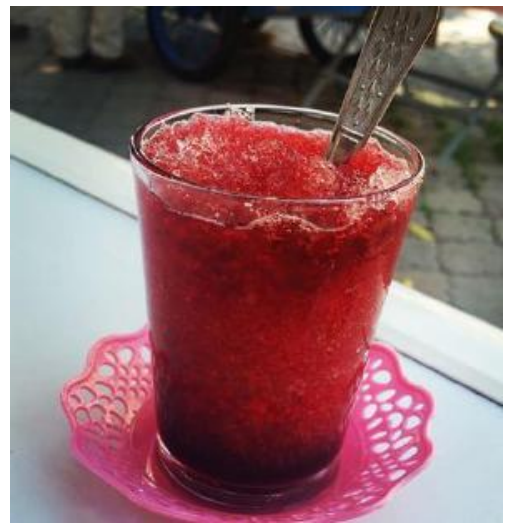

Fig. 7: Nazilli Kar Helva.

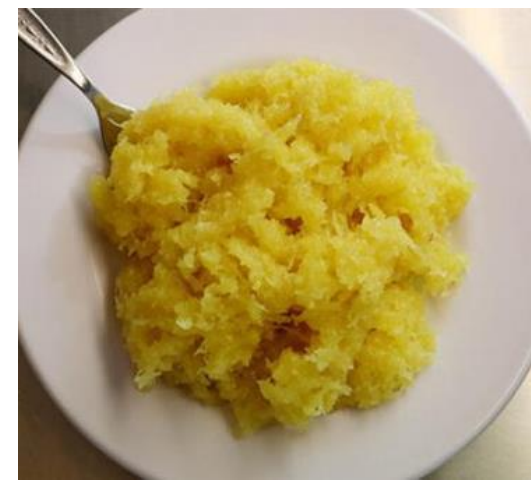

Fig. 8: Tekirdağ Peynir Helva [22].

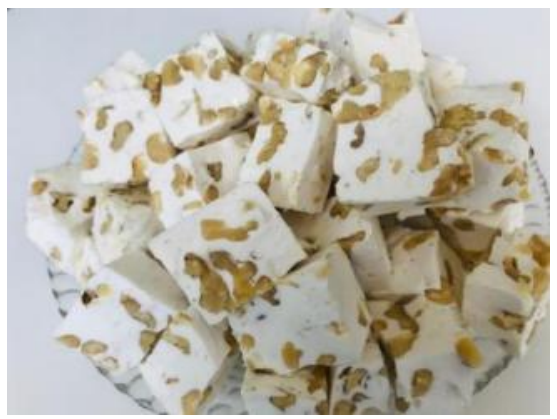

Fig 9: Gerede Şakşak Helva.

\subsection{Kütahya Köpük (Foam) Helva}

Made in Kütahya province, Kütahya Köpük Helva is produced by mixing beet sugar, water, gypsophila extract (Saponaia officinalis) and lemon salt (citric acid). It is a non-fluid viscous product with a bright white foam appearance, soft consistency. The production of helva in Kütahya goes back to the 1800 's, to the Ottoman Period. Although helva is always consumed, an increase can be seen in its consumption especially in autumn and winter. Helva can also be consumed with tahini on demand.

The amount of ingredients used in the production of Kütahya Köpük Helva: beet sugar $81 \pm 5 \%$, water $18 \pm 5 \%$, gypsophila extract $1 \%$, lemon salt (citric acid) $0.1 \%$. No additives other than lemon salt are added to helva. In the production of helva, sugar, water and lemon salt are mixed in a boiler and heated. When the temperature of the mixture reaches $125-130^{\circ} \mathrm{C}$, the heating process is shut off. This process takes about 45-50 minutes. The final consistency is decided by the master by applying a few drops of a little syrup between the thumb and index finger and checking its structure. $1 \%$ gypsophila extract is added to the syrup, whose temperature is $55-62^{\circ} \mathrm{C}$, and whisked for 1 hour. Gypsophila extract is the main substance that enables the color and flavor of the product to be formed and its foam structure. As a result of the visual inspection by the master, the process is shut off. In the control, $500 \mathrm{~g}$ of helva is placed in a $1000 \mathrm{~g}$ plastic vessel and its volume is controlled. If the helva fills the entire vessel, it means that the product has received sufficient volume, but if it does not fill the vessel completely, it is understood that the whipping process should be continued. If the volume fills the vessel, it does not flow when the vessel is turned upside down, which indicates that the process has been done adequately. The photo of the helva is given in Figure 10 .

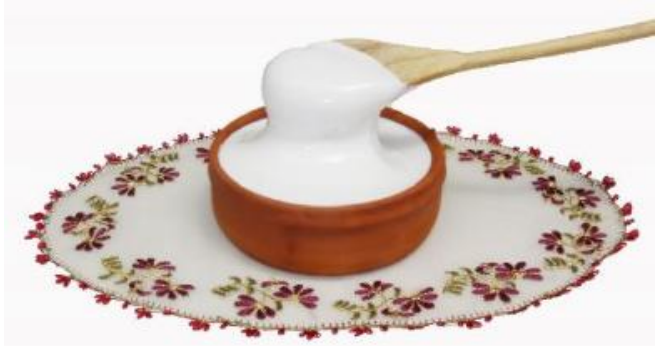

Fig. 10: Kütahya Köpük Helva.

\section{DISCUSSION}

There are 25 pieces of helva with registered geographical indication helva and ongoing registering process geographical indication helva in Turkey. There are also many unique helvas that are produced locally and have not 
Nov-Dec 2020 / Available online: https://ijels.com/

started the geographical indication process. When the geographical indication helvas are examined, it is seen that generally not a wide variety of ingredients are used in their production. As can be seen in Table 6, the ingredients frequently used in the production of geographical indication helva are walnut, gypsophila, sugar, flour and citric acid is added as a preservative. It can be said that the use of eggs in helva improves the appearance of the color of the product and contributes to the formation of texture. It can be said that the production of helva, made by diversifying it with other ingredients except walnut, peanut, almond and hazelnut, is after the ease of obtaining from the market in recent dates. As a matter of fact, it is seen that some ingredients such as glucose, colorant, cocoa or coconut are used in making some helva.

According to the records, even in the Ottoman Palace, although a wide variety of dishes and desserts are made that require effort, it is seen that there is a simple and quiet life in the Kitchen. In addition, the presence of a separate "Helvahane" in the Palace Kitchen shows the importance given to desserts. Although the history of helva dates back to very old times and the materials available at that time were limited, it is obvious that different varieties and flavors were created with very few ingredients but different treatment methods. From here, it is seen how important workmanship or mastery is in production as much as the effect of the ingredients used in the production of helva or dessert, and dessert making methods have developed.

Helva is still used in all kinds of sociological activities in Turkish society. It can be said that many events such as holidays, religious days, marriage, death and commemoration ceremonies are identified with helva. Within the scope of increasing cultural tourism in recent years, especially in gastronomy tours, it is thought that dessert and helva should be considered more as a gastronomic element.

Table 6: Ingredients used in the production of geographical indication helvas.

\begin{tabular}{ll}
\hline Helva Type & Ingredients \\
\hline $\begin{array}{l}\text { Bilecik Pazaryeri } \\
\text { Helva }\end{array}$ & tahini, sugar, water \\
\hline Cide Ceviz Helva & walnut, sugar, egg white, water \\
\hline Kabataş Helva & $\begin{array}{l}\text { walnut, pekmez (pear/apple), } \\
\text { sugar, flour, egg white, citric acid }\end{array}$ \\
\hline Kastamonu Çekme & $\begin{array}{l}\text { sugar, flour, butter / margarine, } \\
\text { citric acid, water, (optional: } \\
\text { pistachio, walnut, almond, } \\
\text { hazelnut, cocoa, chocolate, } \\
\text { coconut, sesame) }\end{array}$ \\
\hline
\end{tabular}

Ordu Perşembe walnut, gypsophila, sugar, citric Ceviz Helva acid, water

\begin{tabular}{ll}
\hline Eskişehir Met Helva & sugar, flour, oil, citric acid, water \\
\hline Nazilli Kar Helva & natural snow, cherry syrup \\
\hline $\begin{array}{l}\text { Tekirdağ Peynir } \\
\text { Helva }\end{array}$ & $\begin{array}{l}\text { cheese, sugar, flour, egg yolk / } \\
\text { colorant }\end{array}$ \\
\hline Gerede Şakşak Helva & $\begin{array}{l}\text { walnut, gypsophila, sugar, } \\
\text { glucose, citric acid }\end{array}$ \\
\hline $\begin{array}{l}\text { Kütahya Köpük } \\
\text { Helva }\end{array}$ & $\begin{array}{l}\text { gypsophila, sugar, citric acid, } \\
\text { water }\end{array}$ \\
\hline
\end{tabular}

\section{CONCLUSION}

One of the only needs of humankind that has not given up throughout human history is nutrition. In the early ages, consuming whatever is available and what is available was the most natural behavior, today, with the development of technology and science, there is an orientation to our health, natural nutrition and more original local food and drink. Socialization comes after the need for safety, shelter and food. For this, communication with people and travel are involved. Traveling to see the traditions and lifestyle of a region is cultural tourism and the preparation and tasting of local foods is gastronomy tourism.

In terms of sustainability, helva holds an important place for gastronomic tourism in the context of the introduction of Turkey's rich cuisine and desserts were prepared to evaluate this article. Turkey's geographical indication is already 10 pieces of helva is introduced with the main aim, in this context, it is advisable to keep in mind the rich culture of Turkish cuisine in the culture tour will take place in Turkey.

\section{APPENDIX}

Table 7: Details of Geographical Indication Process of Helvas.

\begin{tabular}{lllll}
\hline Helva Type & $\begin{array}{l}\text { File } \\
\text { Number }\end{array}$ & $\begin{array}{l}\text { Application } \\
\text { Date }\end{array}$ & $\mathrm{RN}^{*}$ & $\mathrm{RD} *$ \\
\hline $\begin{array}{l}\text { Eskişehir } \\
\text { Met Helva }\end{array}$ & $\mathrm{C} 2010 / 026$ & 12.05 .10 & 250 & 30.11 .17 \\
\hline $\begin{array}{l}\text { Ordu } \\
\text { Perşembe } \\
\text { Ceviz Helva }\end{array}$ & $\mathrm{C} 2011 / 063$ & 29.09 .11 & 283 & 18.12 .17 \\
\hline $\begin{array}{l}\text { Kabataş } \\
\text { Helva }\end{array}$ & $\mathrm{C} 2011 / 070$ & 05.10 .11 & 282 & 18.12 .17 \\
\hline $\begin{array}{l}\text { Nazilli Kar } \\
\text { Helva }\end{array}$ & $\mathrm{C} 2012 / 055$ & 09.03 .12 & 354 & 31.05 .18 \\
\hline
\end{tabular}


Nov-Dec 2020 / Available online: https://ijels.com/

Tekirdağ

Peynir Helva

C2016/011 $05.02 .16 \quad 525 \quad 09.09 .20$

Bilecik

Pazaryeri $\quad$ C2017/133 23.08.17 $290 \quad 27.12 .17$

Helva

\begin{tabular}{lllll}
\hline $\begin{array}{l}\text { Kastamonu } \\
\text { Çekme } \\
\text { Helva }\end{array}$ & C2017/202 & 17.11 .17 & 388 & 17.10 .18 \\
\hline $\begin{array}{l}\text { Cide Ceviz } \\
\text { Helva }\end{array}$ & C2018/182 & 17.09 .18 & 546 & 27.09 .20 \\
\hline $\begin{array}{l}\text { Gerede } \\
\text { Şakşak }\end{array}$ & C2019/168 & 06.11 .19 & 587 & 06.11 .20 \\
Helva & & & & \\
\hline
\end{tabular}

\begin{tabular}{lllll}
\hline $\begin{array}{l}\text { Kütahya } \\
\text { Köpük Helva }\end{array}$ & C2020/085 & 13.03 .20 & 597 & 20.11 .20 \\
\hline $\begin{array}{l}\text { Eskişehir } \\
\text { Nuga Helva }\end{array}$ & C2010/029 & 10.06 .10 & - & \\
\hline $\begin{array}{l}\text { Düzce } \\
\text { Findıklı } \\
\text { Tahin Helva }\end{array}$ & C2017/168 & 31.10 .17 & - \\
\hline
\end{tabular}

\begin{tabular}{lll}
\hline $\begin{array}{l}\text { Gerze Düğ̈un } \\
\text { Helva }\end{array}$ & C2018/104 30.04.18 - \\
\hline
\end{tabular}

\begin{tabular}{llll}
\hline $\begin{array}{l}\text { Deva-i Misk } \\
\text { Helva }\end{array}$ & C2018/247 & 31.12 .18 & - \\
\hline
\end{tabular}

\begin{tabular}{|c|c|c|c|}
\hline $\begin{array}{l}\text { Mudurnu } \\
\text { Basma Helva }\end{array}$ & C2019/120 & 09.09.19 & - \\
\hline $\begin{array}{l}\text { Erzurum } \\
\text { Peynir Helva }\end{array}$ & C2019/178 & 11.11 .19 & - \\
\hline $\begin{array}{l}\text { Kahta } \\
\text { Bademli } \\
\text { İrmik Helva }\end{array}$ & C2020/019 & 17.01 .20 & - \\
\hline Paşa Helva & C2020/081 & 13.03 .20 & - \\
\hline $\begin{array}{l}\text { Kütahya } \\
\text { Bitli Helva }\end{array}$ & C2020/084 & 13.03 .20 & - \\
\hline $\begin{array}{l}\text { Aksaray } \\
\text { Köpük Helva }\end{array}$ & C2020/200 & 17.07.20 & - \\
\hline $\begin{array}{l}\text { Antep } \\
\text { Peynirli } \\
\text { İrmik Helva }\end{array}$ & C2020/205 & 20.07 .20 & - \\
\hline $\begin{array}{l}\text { Bursa Süt } \\
\text { Helva }\end{array}$ & C2020/236 & 20.08 .20 & - \\
\hline $\begin{array}{l}\text { Konya } \\
\text { Kenevir } \\
\text { Helva }\end{array}$ & C2020/261 & 15.09 .20 & - \\
\hline
\end{tabular}

Konya

Haside

Tatlisı (Kara

C2020/292 17.09.20

Helva)

Konya İrmik

Helva

C2020/318 24.09.20

*RN: Registration Number, RD:Registration Date.

Table 7: Details of Geographical Indication Process of Helvas (continuous).

\begin{tabular}{|c|c|c|c|}
\hline Helva Type & Province & Applicant / Registrant & $\mathrm{S}^{*}$ \\
\hline $\begin{array}{l}\text { Eskişehir Met } \\
\text { Helva }\end{array}$ & Eskişehir & $\begin{array}{l}\text { Eskişehir Chamber of } \\
\text { Commerce }\end{array}$ & $\mathrm{R}$ \\
\hline $\begin{array}{l}\text { Ordu } \\
\text { Perşembe } \\
\text { Ceviz Helva }\end{array}$ & Ordu & Ordu Governorship & $\mathrm{R}$ \\
\hline Kabataş Helva & Ordu & Ordu Governorship & $\mathrm{R}$ \\
\hline $\begin{array}{l}\text { Nazilli Kar } \\
\text { Helva }\end{array}$ & Aydin & $\begin{array}{l}\text { Nazilli Chamber of } \\
\text { Commerce }\end{array}$ & $\mathrm{R}$ \\
\hline $\begin{array}{l}\text { Tekirdağ } \\
\text { Peynir Helva }\end{array}$ & Tekirdağ & $\begin{array}{l}\text { Tekirdağ Chamber of } \\
\text { Commerce and } \\
\text { Industry }\end{array}$ & $\mathrm{R}$ \\
\hline $\begin{array}{l}\text { Bilecik } \\
\text { Pazaryeri } \\
\text { Helva }\end{array}$ & Bilecik & $\begin{array}{l}\text { Bilecik Chamber of } \\
\text { Commerce and } \\
\text { Industry }\end{array}$ & $\mathrm{R}$ \\
\hline $\begin{array}{l}\text { Kastamonu } \\
\text { Çekme Helva }\end{array}$ & $\begin{array}{l}\text { Kastamon } \\
\mathrm{u}\end{array}$ & $\begin{array}{l}\text { Kastamonu Chamber } \\
\text { of Commerce and } \\
\text { Industry }\end{array}$ & $\mathrm{R}$ \\
\hline $\begin{array}{l}\text { Cide Ceviz } \\
\text { Helva }\end{array}$ & $\begin{array}{l}\text { Kastamon } \\
\mathrm{u}\end{array}$ & Cide Municipality & $\mathrm{R}$ \\
\hline $\begin{array}{l}\text { Gerede Şakşak } \\
\text { Helva }\end{array}$ & Bolu & $\begin{array}{l}\text { Gerede Chamber of } \\
\text { Commerce and } \\
\text { Industry }\end{array}$ & $\mathrm{R}$ \\
\hline $\begin{array}{l}\text { Kütahya } \\
\text { Köpük Helva }\end{array}$ & Kütahya & $\begin{array}{l}\text { Kütahya Commodity } \\
\text { Exchange }\end{array}$ & $\mathrm{R}$ \\
\hline $\begin{array}{l}\text { Eskişehir } \\
\text { Nuga Helva }\end{array}$ & Eskişehir & $\begin{array}{l}\text { Eskişehir Chamber of } \\
\text { Commerce }\end{array}$ & A \\
\hline $\begin{array}{l}\text { Düzce Findıklı } \\
\text { Tahin Helva }\end{array}$ & Düzce & $\begin{array}{l}\text { Düzce Provincial } \\
\text { Directorate of } \\
\text { Agriculture and } \\
\text { Forestry }\end{array}$ & A \\
\hline $\begin{array}{l}\text { Gerze Düğün } \\
\text { Helva }\end{array}$ & Sinop & Gerze Municipality & A \\
\hline $\begin{array}{l}\text { Deva-i Misk } \\
\text { Helva }\end{array}$ & Edirne & $\begin{array}{l}\text { Edirne Commodity } \\
\text { Exchange }\end{array}$ & A \\
\hline
\end{tabular}


Nov-Dec 2020 / Available online: https://ijels.com/

Mudurnu

Basma Helva Bolu Mudurnu Municipality A

\begin{tabular}{|c|c|c|c|}
\hline $\begin{array}{l}\text { Erzurum } \\
\text { Peynir Helva }\end{array}$ & Erzurum & $\begin{array}{l}\text { Erzurum Commodity } \\
\text { Exchange }\end{array}$ & A \\
\hline $\begin{array}{l}\text { Kahta Bademli } \\
\text { İrmik Helva }\end{array}$ & Adiyaman & Kahta Municipality & A \\
\hline Paşa Helva & Kütahya & $\begin{array}{l}\text { Kütahya Commodity } \\
\text { Exchange }\end{array}$ & A \\
\hline $\begin{array}{l}\text { Kütahya Bitli } \\
\text { Helva }\end{array}$ & Kütahya & $\begin{array}{l}\text { Kütahya Commodity } \\
\text { Exchange }\end{array}$ & A \\
\hline $\begin{array}{l}\text { Aksaray } \\
\text { Köpük Helva }\end{array}$ & Aksaray & Aksaray Municipality & A \\
\hline $\begin{array}{l}\text { Antep Peynirli } \\
\text { İrmik Helva }\end{array}$ & Gaziantep & $\begin{array}{l}\text { Gaziantep } \\
\text { Metropolitan } \\
\text { Municipality }\end{array}$ & A \\
\hline $\begin{array}{l}\text { Bursa Süt } \\
\text { Helva }\end{array}$ & Bursa & $\begin{array}{l}\text { Bursa Chamber of } \\
\text { Commerce and } \\
\text { Industry }\end{array}$ & A \\
\hline $\begin{array}{l}\text { Konya } \\
\text { Kenevir Helva }\end{array}$ & Konya & $\begin{array}{l}\text { Konya Metropolitan } \\
\text { Municipality }\end{array}$ & A \\
\hline $\begin{array}{l}\text { Konya Haside } \\
\text { Tatlisı (Kara } \\
\text { Helva) }\end{array}$ & Konya & $\begin{array}{l}\text { Konya Metropolitan } \\
\text { Municipality }\end{array}$ & A \\
\hline $\begin{array}{l}\text { Konya İrmik } \\
\text { Helva }\end{array}$ & Konya & $\begin{array}{l}\text { Konya Metropolitan } \\
\text { Municipality }\end{array}$ & A \\
\hline
\end{tabular}

*S:Status; R-registered, A-application.

\section{REFERENCES}

[1] Büyüktuncer, Z., \& Yücecan, S. (2009). Nutrition and health evaluation of Turkish Cuisine. J Nutr and Diet, 37(12), 93-100.

[2] Eren, S. (2019). A study on the relationship between the use of traditional desserts in tourist restaurants with the online gastronomic image and gastronomic experience. 4th International Gastronomy Tourism Studies Congress, Process Book. ISBN: 978-605-031-271-3. Nevşehir. 149158.

[3] Yerasimos, M. (2019a). 500 years old Ottoman Cuisine. İstanbul, Boyut Publishing. ISBN:978-975-23-0111-55.

[4] Şavkay, T. (2000). Ottoman Cuisine. Şekerbank, Press and Public Relations Directorate.

[5] Yerasimos, M. (2019b). Food culture in Evliya Çelebi's travel book - comments and systematic index. İstanbul, Yap1 Kredi Publishing, ISBN:978-975-08-4568.

[6] Oturakçı Orbay, N. (2018). An onomastic approach to dessert names in turkish. International Journal of Languages' Education and Teaching, 6(1), 396-413.

[7] Işıı, P. M. (2019). Gülbeşeker: The history of Turkish sweets. İstanbul, Yapı Kredi Publications, ISBN: 978-97508-1499-0.
[8] Y1lmaz, G. \& Akman, S. (2019). Gastronomic value of halva and helva-i gazi from ottoman to present. Gastroia: Journal of Gastronomy and Travel Research, 3(3), 462-469.

[9] Sevimli, Y., \& Sönmezdağ, A. S. (2017). Special day desserts: importance in terms of cultural tourism. International Rural Tourism and Development Journal, $1(2), 18-28$.

[10] Aktaş, N., \& Cebirbay, M. A. (2010). A traditional helva in Turkey: Koz helva. J. Food Agric. Environ, 8, 213-215.

[11] Seçim, Y. (2018). Evaluation of Seljuk and Ottoman Cuisine in terms of gastronomy. Journal of Tourism Theory and Research, 4(2), 122-132.

[12] Işın, P.M. \& Çakmak, M. (2020). Oriental confectionery: Friedrich Unger, confectioner of King Otto I of Greece. İstanbul, Yap1 Kredi Publications, ISBN: 978-975-084704-2.

[13] Erdoğan, M. (2010). A teratise introduced to sadrazam damad Ibrahim Pasha in halva conversations: Kelam-i kibar treatise by ilmi Ahmed Efendi, Cumhuriyet Üniversity, Journal of the Faculty of Theology, 14(2), 487-503.

[14] Sevimli, Y. (2019). History of dessert culture in Turkish Cuisine. 4th International Gastronomy Tourism Studies Congress, Process Book. ISBN: 978-605-031-271-3. Nevşehir. 289-298.

[15] Zengin, B., Uyar, H., \& Erkol, G. (2015). A conceptual review on gastronomy tourism. 15th National Tourism Congress, Process Book, Ankara, 1-16.

[16] Url-1 https://www.ci.gov.tr/anasayfa Access date:01.12.2020.

[17] Url-2: https://www.ci.gov.tr/sayfa/co\%C4\%9Frafii\%C5\%9Faret-nedir Access date:01.12.2020.

[18] Kargiglioğlu, Ş., Bayram, G. E., \& Çetin, Y. (2019). Creating gastronomy tours via geographical indications: the example of western black sea tours. Gastroia: Journal of Gastronomy and Travel Research, 3(4), 624-639.

[19] Oraman, Y. (2015). Geographical indication products in Turkey. Balkan and Near Eastern Journal of Social Sciences, 1, 1, 76-85.

[20] TSI-Turkish Standards Institute. TS 13028, Çekme helva (Special Turkish sweet).

[21] Url-3: https://eskisehir.ktb.gov.tr/TR-149937/met-ve-nugahelvasi.html 03.12.2020 Access date: 01.12.2020.

[22] Url-4: https://lezzetler.com/peynir-helvasi-tekirdagvt29109 Access date: 03.12.2020. 